\title{
MURABAHA-RELATED CREDIT RISK AND FINANCIAL PERFORMANCE OF ISLAMIC BANKS IN AFRICA
}

\author{
Dr. Muftau A. Ijaiya \\ Department of Finance \\ University of Ilorin, Nigeria \\ E-mail:muftau@unilorin.edu.ng \\ Abdulrazaq T. Jimoh \\ Department of Finance \\ University of Ilorin, Nigeria \\ E-mail: jimoh.at1@unilorin.edu.ng \\ John A. Attah \\ Ph.D. Student \\ Department of Accounting \\ Faculty of Administration \\ Nasarawa State University, Keffi, Nigeria \\ E-mail: attahjohnadeyimorandy@gmail.com \\ Dr. Biliqees A. Abdulmumin \\ Department of Finance \\ University of Ilorin \\ E-mail: abdulmumin.ba@unilorin.edu.ng \\ Aliyu I. Nafiu \\ Department of Accountancy \\ Federal Polytechnic, Offa \\ Kwara State, Nigeria
}

\begin{abstract}
The uniqueness of Murabaha (cost-plus) financing has suggested another theoretical relationship between credit risk and the financial performance of banks. While studies from Asian countries supported this assertion, empirical analyses from Africa reported conventional findings on the credit risk effect on performance. These conflicting reports were partly due to the exclusion of factors specific to Murabaha financing in past studies in Africa. This study was conducted to assess the effect of credit risk on the financial performance of Islamic banks in Africa. Data were collected from annual reports of the selected Islamic banks for nine years from 2012 to 2020. A fixed-effect regression model was estimated after conducting the preliminary tests of Breusch Pagan Lagrange Multiplier (BP/LM) and Hausman. The study found that non-performing Murabaha (0.0220) and provision for impairment of Murabaha financing (0.3506) have positive effects on return on assets. The results were found to be significant at a $5 \%$ level of significance.
\end{abstract}


Based on this finding, it was concluded that credit risk exposure that arises from Murabaha (transactions) financing tends to improve the financial performance of the banks. Therefore, the study recommends that Islamic banks increase their financing of Murabaha transactions to boost their profitability and compensate for high credit risk exposure.

Keywords: Africa, Credit Risk, Financial Performance, Murabaha.

\section{JEL Classification Codes: G21, G32.}

\section{INTRODUCTION}

The uniqueness of Islamic banking transactions like Murabaha (cost plus mark-up) has suggested a new direction to the theoretical relationship between credit risk and the financial performance of banks. In a Murabaha transaction, the bank buys the items under the customer specifications and sells them at the cost plus profit element. The customer then settles the bank at a future agreed date or through some agreed installments. According to Ahmed (2010), Murabaha is the most popular product, accounting for about $80 \%$ of Islamic banks' transactions. This implies that the product represents an important asset of Islamic banks, and the quality of such asset affects the financial performance, particularly the banks' profitability. To maintain good asset quality, associated credit risk must be managed appropriately.

The credit risk in the Islamic banking product of Murabaha comes from the inability of a customer (buyer) to settle his debt when the goods are delivered or when he fails to complete the installment payments as agreed with the bank (Boumediene, 2011). Another way credit risk arises in a Murabaha financing is when the buyer refuses to take delivery of the product purchased after the bank might have paid for the supply of the goods. This occurs typically in non-binding Murabaha when the customers feel that the goods could not meet his specification (Iqbal \& Mirakhor, 2011).

In Africa, Islamic banks are exposed to high credit risk to meet the intermediation demands of the economy. Adewale and Elena (2019) identified some reasons for the high level of credit risk associated with Islamic banking transactions in the region. The grounds specified were the challenges of lending in Africa, which feature lack of valuable securities to be presented as collateral for bank lending, absence of good titles to properties, lack of presentable business plans in most cases, and lack of proper financial documentation. Financing a business that exhibits these traits has resulted in repayment default in some Islamic banks in Africa. Provision of finance to risk economic sector (risk sector financing) is another factor responsible for high credit risk in Islamic banks in Africa. Adewale and Elena (2019) state that after Murabaha financing, risk sector financing is the second largest contributor to high credit risk in the Islamic banking sector of Africa. Lastly, the issue of regulation and compliance is another challenge for Islamic banking in Africa. According to Ariffin and Tafri (2014), some banks have some ambiguous fees, which may be seen as interests designed in the form of management fees which cumulate to the high cost of accessing financing of Islamic banks and eventual default in repayment.

Therefore, it is evident that high credit risk is associated with Islamic banking. The primary source of the risk is the Murabaha financing, which represents the most significant portion of Islamic banking financing transactions. The effect of credit risk on the financial performance of Islamic banks is not expected to be in the same direction as in conventional banks. This is primarily due to the nature of Islamic banking in general and the nature of Murabaha financing in particular, 
in which mark-up is added to the cost of financing depending on the risk associated with the transaction.

Thus, a positive rather than negative relationship might be expected between credit risk and financial performance, contradicting the theoretical assumption (bad management hypothesis) that the higher the accumulated unpaid loans and advances, the lower the profitability. This is particularly so with interest, which is compounded by the outstanding balance throughout loans. The position on the positive effect of credit risk on the financial performance of Islamic banks was buttressed by Tafri, Hamid, Meera, \& Omar (2009) that high credit risk tends to boost the financial performance of Islamic banks as customers will be made to remit higher share of profit as compensation for taking higher credit risk.

Confirming the uniqueness of the banking system and its products, studies in Asia have reported positive results on the relationship between credit risk and financial performance of Islamic banks (Bashir, 2003; Tafri et al., 2009; Ramadan, 2011; Supiyadi, Dodi, \& Machmud, 2017). In Africa, only a few studies are available on credit risk and Islamic bank performance (Karim, Mohamed Sami, \& Hichem, 2010; Chowdhury \& Rasid, 2015; Mong'are, 2015). All of these studies found a negative relationship that aligned with findings of many conventional banks (Onaolapo, 2012; Kolapo, Ayeni, \& Oke, 2012; Kurawa, 2014; Kingu, Macha, \& Gwahula, 2015), as well as the established theoretical explanation.

A further review of past studies in Africa indicated that research works on Islamic banks had not considered Murabaha financing as a variable of interest when assessing the relationship between credit risk and performance. Unlike the studies from Asia, no specific measure of credit risk exposure from Murabaha financing was captured by the past studies in Africa. It, therefore, becomes imperative to investigate the effect of credit risk on the financial performance of Islamic Banks in Africa. This is to examine further the uniqueness of the Islamic banking product of Murabaha financing and how credit risk from Murabaha financing affects the profitability of Islamic banks in Africa.

The remainder of this paper was structured to include a literature review, methodology, results, and discussion.

\section{LITERATURE REVIEW}

Some empirical studies have investigated the relationship between credit risk and the financial performance of Islamic banks. Bashir (2003) examined the performance indicators of Islamic banks from 8 countries in the Middle East. Credit risk was proxy by capital-to-asset and loan-toasset ratios, while performance was measured with ROA and ROE. Cross-country bank-level data was obtained from annual financial statements of 14 Islamic banks for periods from 1993 to 1998. Pooled OLS regression was conducted to analyze the data. The study found that credit risk affects performance positively and significantly. Results showed that high capital-to-asset and loan-toasset ratios result in increased profitability in the selected banks. In Malaysia, Tafri et al. (2009) considered a credit risk a determinant of Islamic bank profitability. The study arrived at the same conclusion as Bashir (2003) that a positive relationship exists between credit risk and bank profitability.

Ramadan (2011) investigated the bank-specific determinants of profitability of Jordanian Islamic banks from 2000 to 2010. Amman stock exchange and Central Bank of Jordan were collected on variables on the study, including credit risk. The credit risk was measured by the ratio of loan loss provision to total loan. Using the regression analysis technique, the study found that credit risk is significantly associated with Islamic banks' profitability (measured by return on 
asset). That is, higher profitability is attributable to increased credit risk exposure in the banks. The findings on credit risk were consistent with Ramadan (2011) that a positive relationship exists between credit risk (proxy with the total loan to total asset) and profitability (indicated by return on assets).

Supiyadi et al. (2017) investigated the relationship between credit risk management and Islamic Banking performance in Indonesia. Data used for the study were collected from the banks listed on the Indonesian Stock Exchange for 2007 and 2016. Regression analysis was carried out to determine the effect of credit risk on performance. The study found that non-performing financing and capital adequacy ratios used as a proxy for credit risk were found to have a positive and significant effect on the profitability of Islamic banks, measured by return on asset and return on equity.

The Asia studies reviewed found that credit risk is positively related to Islamic bank performance. However, the reverse was the case for studies from Africa as this new, unusual relationship found for Asian banks could not be established in Africa. Adewale and Elena (2019) suggested that lending challenges (collateral issues, absence of property title, thin business plan, and so on), risk sector financing concentration, and lack of adequate guidance on Islamic banking in Africa culminated in poor credit risk management, which affects bank performance negatively in the region. Karim et al. (2010) studied the factors that affect the profitability of Islamic banks in Africa from 1999 to 2009. A sample of 9 Islamic banks from Egypt, Sudan, and Tunisia was selected, and data were collected from the Bank Scope database. The result of regression analysis revealed that net loan to the total asset (a proxy of credit risk) exhibits a negative and significant impact on bank profitability. This implies that high credit risk exposure reduces profitability. This finding was contrary to Srairi (2010), which measured credit risk with the same net loan to the total asset but reported a positive relationship with the profitability of Islamic banks in the Gulf Cooperation Council.

Furthermore, Chowdhury and Rasid (2015) analysed the factors that influence the profitability of 44 selected Islamic banks from Africa. Data were collected from the BankScope database and analysed using the ordinary least square method of regression. The study found that the ratio of loan loss provision to total loan (an indicator of credit risk) was negatively correlated with bank profitability, suggesting that higher credit risk leads to lower profitability. The finding was in tandem with Mong'are (2015), who assessed the effect of risk management on the financial performance of Islamic banks in Kenya from 2010 to 2014. Both descriptive and inferential analysis was used to analyse the data collected for the study. Multiple regression analysis was to evaluate the significance of the relationship between risk measures and the financial performance of the banks. A negative and significant effect of credit risk was found on the Performance of Islamic banks in Kenya.

A review of empirical studies revealed that while studies from Asia reported positive effects of credit risk on financial performance and were consistent with risk-return trade-off theory, those from Africa showed adverse effects in line with the bad management hypothesis. Following the position occupied by Murabaha financing and the uniqueness of Islamic banking operations (such as asset-based financing), it might not be too much to think that the relationship between credit risk and financial performance is expected to be positive. The few studies in Africa didn't consider non-performing Murabaha transactions specifically in measuring their credit risk. These might have affected their results and conclusion drawn on the relationship between credit risk and financial performance. This study included this important variable in its empirical investigation. 
This study was hinged on the bad management theory and trade-off principle of risk and return embedded within the portfolio theory. The bad management hypothesis holds that low performance in terms of profitability and efficiency of the bank results from poor management decisions reflected in the poor credit management (Berger \& DeYoung, 1997). According to this hypothesis, poor monitoring of credit and poor screening of borrowers on the part of bank management tends to increase the amount of Non-performing loans leading to low profitability. While explaining the bad management theory, Podpiera and Weill (2008) stated that low performance relates to increased non-performing loans or financing, and this may be connected with bad management practices in the area of proposal and collateral appraisal, as well as monitoring the borrowing customer to ensure repayment as agreed.

The theory could therefore be used to explain the effect of credit risk on the performance of banks in terms of profitability. This is because high-risk exposure without proper management reflects bad managerial capability, which can increase the operating cost and reduce the banks' profitability. However, the reports of studies of Asian Islamic banks contradict the theoretical hypothesis Berger and DeYoung (1997). The reason proffered was that the operation of Islamic banks is quite different from conventional ones, and high credit risk exposure allows the banks to add higher mark-up leading to higher profitability. As a result, the study considered the theory of risk-return trade-off of Markowitz (1968) and Sharpe (1964).

The application of trade-off theory can be extended to the relationship between credit risk and the financial performance of Islamic banks. According to Markowitz (1968) and Sharpe (1964), the theory holds that a trade-off exists between risk and return. That is, the higher the risk an investor (lender) will be ready to accept depends on the availability of commensurately higher expected return. This principle is embedded in the traditional economic model of portfolio theory that higher returns are expected from riskier investments. The theory holds that risky assets have to promise high average returns for risk-averse investors to be motivated to take up such investments. A positive relationship is therefore expected between risk and

About credit risk associated with Islamic banking products especially, Murabaha transaction, the theory explains the trade-off between the risk that Murabaha financing will end in a default on the part of the customer (buyer) with a consequential loss to the bank, and the return that the bank will charge and receive on the transaction in the form of profit (mark-up). The analysis of the risk-return trade-off as enshrined in theory is the hallmark of all decisions on risky investments, which must incorporate expected credit losses. Therefore, it follows that if the bank exposure (risk of default) in Murabaha financing is high, then the profit element, the return on investment to the bank, should be commensurately increased. Ramadan (2011) and Supiyadi et al. (2017) reported findings consistent with the theory.

This theory implies that a positive rather than negative effect of credit risk as assumed by risk management theory is expected on the Performance of Islamic banks. This is because the credit risk associated with Murabaha financing causes the banks to add higher mark-up as rewards for the high credit risk, thus boosting the bank's profitability.

\section{METHODOLOGY}

This study employed an ex-post facto design to assess the effect of credit risk on the financial performance of Islamic banks in Africa. Twenty Islamic banks were selected purposively from low-income countries of Africa. The study covered a period of nine years from 2012 to 2020. Data were collected from annual reports of the selected banks and analysed using both descriptive and inferential statistics. Breusch Pagan Lagrange Multiplier (BP/LM). Hausman tests were conducted 
to choose the most appropriate estimation technique. Fixed effect model estimation was used to explain the effect of credit risk and other (control) variables on the financial performance of the selected Islamic banks.

The model for this study followed Mennawi (2020), and the relationship between credit risk and financial performance of Islamic banks is specified as follows.

Financial Performance $=f$ (Credit Risk relating to Murabaha and control variables $)$

FinPerf $=f($ NPMR, MFIp, CAR, SMF, SIZE, LEV $)$

Financial performance is measured by return on asset (ROA). ROA is a more reliable measure of profitability when compared with other traditional performance indicators (Bikker, 2010). The econometric models of the relationship are specified as follows:

$R O A_{i t}=\alpha+\beta_{1} N P M r_{i t}+\beta_{2} M F I p_{i t}+\beta_{3} C A R_{i t}+\beta_{4} S M F_{i t}+\beta_{5} S I Z E_{i t}+\beta_{6} L E V_{i t}+\mu_{i t}$

Where; ROA = Return on Asset; NPMr= Non-performing Murabaha financing ratio; MFIp = Murabaha financing Impairment Provision ratio; $\mathrm{CAR}=$ Capital Adequacy Ratio; SMF = Size of Murabaha Financing; SIZE = Bank Size; LEV = Leverage.

Apriori expectation was that $\beta_{1}<0, \beta_{2}<0, \beta_{3}>0, \beta 4>0, \beta_{5}>0, \beta_{6}>0, \beta_{7}>0, \beta_{8}>0$. This means that a negative relationship is expected between each non-performing financing ratio and nonperforming financing provision and return on the assets. In contrast, a positive relationship is expected from other explanatory variables.

\section{RESULTS}

Results of data analysis are presented in the form of descriptive and inferential statistics in this section.

Table 1. Tests of Multicollinearity of Independent variables

\begin{tabular}{|l|c|c|c|c|c|c|c|c|c|c|}
\hline Variable & NPFR & MPFP & MFIP & NPMR & CAR & SMF & SIZE & LEV & VIF & TOLs \\
\hline MFIP & 0.19 & 0.11 & 1.00 & & & & & & 1.47 & 0.68 \\
\hline NPMR & 0.12 & 0.25 & 0.16 & 1.00 & & & & & 1.33 & 0.75 \\
\hline CAR & -0.08 & -0.17 & -0.34 & -0.13 & 1.00 & & & & 1.28 & 0.78 \\
SMF & 0.24 & 0.14 & 0.07 & 0.21 & 0.09 & 1.00 & & & 1.53 & 0.65 \\
\hline SIZE & 0.41 & 0.33 & 0.23 & 0.19 & 0.29 & 0.17 & 1.00 & & 1.44 & 0.69 \\
\hline LEV & 0.02 & 0.09 & 0.10 & 0.07 & 0.21 & 0.18 & 0.34 & 1.00 & 1.34 & 0.75 \\
\hline
\end{tabular}

Source: Author's Computation (2021)

In Table 1, the results of correlation analysis and variance inflation factor test are presented. The correlation results indicate that the relationship between pairs of variables used as predictors 
is low and weak. This is expected as a strong correlation between independent variables indicates collinearity, which is a serious violation of the Least Squares regression technique.

The variance inflation factor (VIF) measures the degree of correlation between one independent variable and another. As a rule of thumb, a variable is highly collinear when the VIF is greater than 10, but collinearity does not exist where VIF is lesser than 10. A VIF of exactly 1 means that correlation is absent. As can be seen from the table, the VIFs are slightly greater than 1 , meaning a low relationship between the predictor variables. This is supported by tolerance levels (TOLs) which is the inverse of this, the results being significantly higher than the common threshold of 0.20 . Hence, there is no tendency that the standard errors of the regression coefficients would have been erroneously inflated.

Model Estimation Results

Table 2. Credit risk and Return on Asset

\begin{tabular}{|c|c|c|c|}
\hline ROA & $\begin{array}{l}\text { POOLED } \\
\text { OLS }\end{array}$ & $\begin{array}{c}\text { FIXED } \\
\text { EFFECTS }\end{array}$ & $\begin{array}{c}\text { RADOM } \\
\text { EFFECTS }\end{array}$ \\
\hline Constant & $\begin{array}{l}-4.2232 \\
(2.2621)\end{array}$ & $\begin{array}{l}-5.7034 \\
(4.0331)\end{array}$ & $\begin{array}{l}-3.6168 \\
(4.2530)\end{array}$ \\
\hline MFIP & $\begin{array}{l}0.7854 * * \\
(0.1498)\end{array}$ & $\begin{array}{l}0.3506 * * \\
(0.5643)\end{array}$ & $\begin{array}{l}0.6465 * * \\
(0.2443)\end{array}$ \\
\hline NPMR & $\begin{array}{c}0.5329 * * \\
(0.0149)\end{array}$ & $\begin{array}{l}0.0220 * * \\
(0.0232)\end{array}$ & $\begin{array}{c}0.0074 * * \\
(0.0147)\end{array}$ \\
\hline CAR & $\begin{array}{c}0.3669 \\
(0.0688)\end{array}$ & $\begin{array}{c}0.2921 \\
(0.0661)\end{array}$ & $\begin{array}{c}0.3589 \\
(0.0682)\end{array}$ \\
\hline SMF & $\begin{array}{l}4.2105 * * \\
(0.0311)\end{array}$ & $\begin{array}{l}3.3223^{* *} \\
(0.0010)\end{array}$ & $\begin{array}{l}2.5530 * * \\
(0.0423)\end{array}$ \\
\hline SIZE & $\begin{array}{c}0.7161 \\
(0.4557)\end{array}$ & $\begin{array}{c}1.0410 \\
(0.4390)\end{array}$ & $\begin{array}{c}0.7539 \\
(0.3400)\end{array}$ \\
\hline LEV & $\begin{array}{c}0.0033 \\
(0.0110)\end{array}$ & $\begin{array}{c}0.0048 \\
(0.0108)\end{array}$ & $\begin{array}{c}0.0035 \\
(0.0112)\end{array}$ \\
\hline F-stat/Wald $X^{2}$ & $7.032^{* * * *}$ & $9.241^{* * * *}$ & $30.920^{* * * *}$ \\
\hline $\begin{array}{c}\text { Hausman test: } \mathrm{X}^{2} \\
\text { BP LM test }\end{array}$ & $\begin{array}{c}- \\
0.001\end{array}$ & $\begin{array}{c}25.73^{* * *} \\
-\end{array}$ & - \\
\hline R-squared & 0.66 & 0.79 & 0.64 \\
\hline
\end{tabular}

Table 2 presents and compares the results of Pooled ordinary least (POLS), Fixed and Random Effects regression estimates. Also displayed in the table are the results of the Breusch Pagan Lagrange Multiplier (BP/LM) test, which was used to choose between the simple OLS and Random Effects models estimations. Hausman's tests result was also presented in the table to select the better estimates between Fixed and Random Effects Model estimates.

From Table 2, the Breusch Pagan LM test result shows a $p$-value $(0.001)$ which is less than the alpha value of 0.05 , implying that the null hypothesis should be rejected. The underlying hypothesis of the Breusch Pagan LM test is that the variance of the random effect is zero. This means that it will be inappropriate to estimate the model with the use of the POLS. Buttressing 
this fact, the result of the Hausman test shows a value of 25.73, and this is high and significant as the calculated p-value was also found to be lower than the significance level of $1 \%$. The null hypothesis that the differences between the estimated parameters yielded by the two estimation techniques are not systematic is rejected. In other words, there is a significant difference between the estimates of the two estimation techniques.

Based on these results of preliminary tests (Breusch Pagan LM and Hausman tests), the Fixed Effects method, which produces better results for the model, was therefore employed as a regression analysis method in this study. Thus, fixed effect estimates explain the effect of credit risk and other (control) variables on the financial performance of the selected Islamic banks.

According to Table 2, a positive and significant relationship was found between the nonperforming Murabaha financing ratio (NPMr) and ROA. This means that return on assets tends to increase slightly by $0.02 \%$ with a slight increase in NPR. The relationship was found to be significant at a 0.05 level of significance. Similarly, the provision for Murabaha financing impairment (MFI) had a positive effect on the financial performance of the banks as a rise in the rate of the provision is capable of bringing a fall to return on assets. The coefficient value of 0.35 indicates that an increase of $1 \%$ MFIp will increase the return on assets by $0.35 \%$. The effect of the impairment provision on return on assets is significant at a 5\% alpha level.

In the same vein, the size of Murabaha financing (SMF), bank size (SIZE), capital adequacy ratio (CAR), and leverage (LEV) were found to have positive effects on the return on assets of the banks. The size of Murabaha financing measures the number of Islamic bank's assets in cost-plus transactions. The higher the investment in this financing mode, the higher the banks' profitability since the financing size goes a long way in determining the profit element on the transaction. Although the table revealed the significant effect of the Murabaha financing in terms of its size (SMF) on the return on asset (at $5 \%$ level of significance), CAR, Size, and leverage were found with no significant effects on the financial performance of the banks.

In terms of the Fixed Effects model's fitness (goodness of fit), the R-Squared value of 0.79 shows that variations in the credit risk variables explained $79 \%$ of the systematic variations in returns on assets.

\section{DISCUSSION}

The study found that non-performing Murabaha financing and provision for impairment of Murabaha financing were both found to have a positive and significant effect on the financial performance of the selected Islamic banks. In the case of non-performing Murabaha financing, the result suggests that higher profits are charged on cost-plus financing transactions when the credit risk exposure of the banks seemed to be increased. This may be possible when banks consider their past financing records of similar transactions, which will allow them to charge higher on subsequent cases. The finding is in line with Ramadan (2011) and Supiyadi et al. (2017) but inconsistent with Karim et al. (2010).

Similarly, the finding on provision for impairment of Murabaha financing implies that with a high record of non-performing Murabaha financing, the high provision will subsequently be made. This high provision for impairment suggests a high credit risk exposure, making the banks charge higher profits to cover the risk under the risk-return trade-off theory.

The study investigated the effect of credit risk variables on the financial performance of Islamic banks in Africa. It was found from the results of the analysis that the non-performing financing ratio and provision for non-performing financing have adverse effects on return on the asset. In contrast, non-performing Murabaha and provision for impairment of Murabaha have positive 
impacts on return on asset. This is also in agreement with the report of Mong'are (2015) and Chowdhury and Rasid (2015) on the relationship between credit risk and performance. Based on these findings, the study concluded that credit risk exposure that arises from Murabaha (transactions) financing tends to improve the financial performance of the banks. Therefore, this recommends that Islamic banks increase their financing of Murabaha transactions to boost their profitability and compensate for high credit risk exposure. There is also the need to review the costs of other products of Islamic banks, which tends to affect the repayment ability of the customers.

\section{REFERENCES}

Adewale, A.Y. \& Elena, P. (2019). Credit risk and the financial performance of Islamic banks in Africa: A critical literature review. A Conference Paper. Retrieved from https://www.researchgate.net/publication/336554491_Credit_Risk_and_The_Financial_P erformance_of_Islamic_Banks_in_Africa_A_Critical_Literature_Review

Ahmed, A. M. E. T. (2010). Islamic banking: How to manage risk and improve profitability (Vol. 640). John Wiley \& Sons.

Ariffin, A. F., \& Tafri, F. H. (2014). The Impact of Financial Risks on Islamic Banks' Profitability. International Conference on Business, Sociology and Applied Sciences. Retrieved from https://icehm.org/upload/7350ED0314503.pdf

Bikker, J. A. (2010). Measuring performance of banks: an assessment. Journal of Applied Business and Economics, 11(4), 141-159.

Bashir, A. H. M. (2003). Determinants of profitability and rate of return margins in Islamic banks: Some Evidence from the Middle East. Islamic Economic Studies, 11(1), 31-57.

Berger, A. N., \& DeYoung, R (1997). Problem loans and cost efficiency in commercial banks. Journal of Banking and Finance, 21(6), 849-870.

Boumediene, A. (2011). Is credit risk really higher in Islamic banks? Journal of Credit Risk, 7, 97129.

Chowdhury, M. A. F., \& Rasid, M. E. S. M. (2015). The determinants of the profitability of Islamic banks: a cross-sectional study from Asia and Africa. International Journal of Business and Globalisation, 15(3), 375-388.

Iqbal, Z., \& Mirakhor, A. (2011). An introduction to Islamic finance: Theory and practice. Singapore: John Wiley Sons Ltd.

Kurawa, J. M. (2014). An evaluation of the effect of credit risk management on the profitability of Nigerian banks. Journal of Modern Accounting and Auditing, 10(1), 104-115.

Karim, B. K., Mohamed Sami, B. A., \& Hichem, B. K. (2010). Bank-specific, industry-specific and macroeconomic determinants of African Islamic banks' profitability. International Journal of Business and Management Science, 3(1), 39-56. 
Kingu, P.S., Macha, S., \& Gwahula, R. (2015). Impact of non-performing loans on bank's profitability: Empirical evidence from commercial banks in Tanzania. International Journal of Scientific Research and Management, 6(1), 71-79.

Kolapo, T. F., Ayeni, R. K., \& Oke, M. O. (2012). Credit risk and commercial banks performance in Nigeria: A panel model approach. Australian Journal of Business and Management Research, 2(2), 31-38.

Markowitz, H. (1968). Portfolio selection. The Journal of Finance, 7(1), 77-91

Mennawi, A. N. A. (2020). The impact of liquidity, credit, and financial leverage risks on financial performance of Islamic banks: A case of Sudanese banking sector. Risk and Financial Management, 2(2), 59-72

Mong'are, B. M. (2015). The effect of risk management on financial performance of Islamic banks in Kenya. MSc. Thesis. School of Business, University of Nairobi, Kenya. Retrieved from https://pdfs.semanticscholar.org/0a62/00f097060d4be351bc5c32c8090f2d9cbbea.pdf

Onaolapo, A. R. (2012). Nigeria Commercial Banking Sector, (2004-2009), Far East Journal of Marketing and Management, 2(1), 39-52.

Podpiera, J., \& Weill, L. (2008). Bad luck or bad management? Emerging banking market experience. Journal of Financial Stability, 4(2), 135-148.

Ramadan, I. (2011). Bank-specific determinants of Islamic banks profitability: an empirical study of the Jordanian market. International Journal of Academic Research, 3(6), 74-80.

Sharpe, W. F. (1964). Capital asset prices: A theory of market equilibrium under conditions of risk. The Journal of Finance, 19(3), 425-442.

Srairi, S. A. (2010). Cost and profit efficiency of conventional and Islamic banks in GCC countries. Journal of Productivity Analysis, 34(1), 45-62.

Supiyadi, D., Dodi, D., \& Machmud, A. (2017). Factors that influence credit risk of financing institutions in Indonesia. Proceedings of the 2nd International Conference on Economic Education and Entrepreneurship (ICEEE), 159-163.

Tafri, F. H., Hamid, Z., Meera, A. K. M., \& Omar, M. A. (2009). The impact of financial risks on profitability of Malaysian commercial banks: 1996-2005. International Journal of Social, Human Science and Engineering, 3(6), 268-282.

\section{Copyrights}

Copyright for this article is retained by the author(s), with first publication rights granted to the journal. This is an open-access article distributed under the terms and conditions of the Creative Commons Attribution license (http://creativecommons.org/licenses/by/4.0) 